\title{
Archaeologia
}

http://journals.cambridge.org/ACH

Additional services for Archaeologia:

Additional services for Archaeologia:

Email alerts: Click here

Subscriptions: Click here

Commercial reprints: Click here

Terms of use : Click here

\section{I.-Some Chancery Proceedings of the Fifteenth Century}

C. Trice Martin

Archaeologia / Volume 59 / Issue 01 / January 1904, pp 1 - 24

DOI: 10.1017/S0261340900011450, Published online: 15 November 2011

Link to this article: http://journals.cambridge.org/abstract_S0261340900011450

How to cite this article:

C. Trice Martin (1904). I.-Some Chancery Proceedings of the Fifteenth Century. Archaeologia, 59, pp 1-24 doi:10.1017I S0261340900011450

Request Permissions : $\underline{\text { Click here }}$ 


\title{
ARCHAEOLOGIA:
}

or,

\section{ISCELLANEOUS TRACTS,}

$\& c$.

\begin{abstract}
I.-Some Chancery Proceedings of the Fifteenth Century. By C. Trice Martin, Esq., B.A., F.S.A., Assistant Keeper of the Public Records.
\end{abstract}

Read 28th January, 1904.

In the course of my official duties, I have lately been examining the Chancery bills of the fifteenth century. The number of these documents preserved in the Public Record Office is very great. Masses of them have never been seen by the public since they were presented. Now they are being cleaned and arranged, so as to make them accessible to students, and catalogues of them are being printed.

Apart from their legal importance, they will be found to contain information of great value to those interested in the history of families or the history of places. As the subject of a large proportion is the descent of land, they often contain two or three steps of a pedigree, and the names of the houses and fields which are in dispute.

These, however, are not the points which I wish to bring before you to-night but rather to show what light these documents throw on the life of Englishmen several centuries ago.

The bills are petitions to the Chancellor, and may roughly be divided into the following classes:

(1.) Petitions from a person under arrest, who begs for a writ of corpus cum causa directed to the person who has him in custody, to bring him before the Chancellor and explain the reason of his detention, worded as follows, to give one instance :

Wherefore hit wold plese your lordship to send unto the Mayre and Sheriff of the sayd Cite a corpus cum causa, commaunding them to bryng upp tofore you in the Channcerie the body of your besecher and the cause of his arrest, there to be examined and rewled according to conscience.

3 VOL. LIX. 
(2.) Petitions for the removal into Chancery of an action brought against complainant in another court, because the complainant is unable to defend himself in accordance with the rules of the court, or where he does not expect justice to be done.

(3.) Petitions for a writ of subpona to be directed to a person who is injuring complainant in a manner for which he has no redress at common law, or because he is too poor to go to law.

Besides specimens of these classes, I have collected a few merely because of their reference to manners and customs.

To return to the first class mentioned, the bill asking for a corpus cum causa, the kind of arrest most frequently complained of was that made in the City of London under an alderman's commandment, which, as appears by the following documents, prevented the allowance of bail to the person arrested :

\section{Alderman's Commandment.}

Early Chancery Proceedings, Bundle 66, No. 370.

Mekely besecheth youre gode and graciouse lordshipp youre pore oratour Thomas Prowce of London, carpenter, that whereas one John Lambard of London, mercer, made a covenaunt with youre besecher for a. c. marcs to make to the seid John a house and a chapell, after whiche covenaunt so made youre besecher competently and sufficiently made the seid house and chapell accordyng to his seid covenaunt; it is so graciouse lord that youre besecher hathe ben with the seid John for to have his money or sum parte therof. And furthwith the seid John, of verrey malice and evell will and withoute cause, and to that entente for to defraude youre besecher of his seid duete, caused youre besecher to be arrested upon an accion of accompte of .lx. $l i$., wher in trowth youre besecher never receyved of hym ner of none other to his use the value of .xij. $d$. And furthermore the seid John of his seid malice hath caused an alderman to ley his commaundement uppon hym, so that youre besecher can not fynde no maner of suerte nor goo under no maner of bayle. And so he is kept in prison and in grete duresse of irenes ayenst all right and good conscience, to his uttermost undoyng without youre lordshipp be shewyd unto hym in this behalfe.

Bundle 64, No. 706.

Lamentably sheweth unto your gode and gracious lordship your pore and sorowfull oratrice Johanne Blaunder, senglewoman, that whereas now of late sum il disposed persone or persones unto her as yet unknowen, not dreding God nor the jubardy of their soules, but of ther malicious disposicion entending the distruccion of your seid pore besecher, have without 
any ground or cause resonable caused an alderman to ley his commandement upon her. And therupon she was arrest and commytted to ward, wher she is yet and long hath be in right grete peyne and penury, as God knoweth, and none other accion nor mater ageyn her but oonly the seid aldermannys commaundment leyd upon her by the menes of her adversaries, as is aforesaid; to thentent that she shuld not be taken to bayle, but kept still in prisone to her utter undoyng in this world, without your gracious lordship be the more hastyly shewed unto her therin.

\section{Alderman's Commandment. Wager of Law.}

Bundle 64, No. 711.

Sheweth unto your goode and gracioux lordship Thomas Cape of London, iremonger, that where he, late beyng at Cales, desired oon Richard Olyver of London, than beyng in the same toun of Cales, to have lent unto your said oratour .viij. $l i$, the whiche he graunted unto your said oratour and caused hym to make a bill obligatory concernyng the same somme of .viij. li. It was so, gracioux lord, whan the seid bill was made and sealed, the seid Richard wolde not lend to your seid oratour the seid. viij. li. onlesse that a marchaunt of the Staple were bounde with hym for the seid duety. Wheruppon, in so much as your said oratour cowde have no such suyrtie, therfor the seid Richard and your seid oratour cancelled the seid bill. And this notwithstanding, the seid Richard nowe late hathe comensed a feyned accion of dette of .viij. li. ayenst your seid oratour before the Mair and Aldermen of London, and thereuppon caused your said oratour to be arrested. And according to the custome of London your said oratour came to have waged his lawe, and brought .xij. sufficient men, dwellers within London, whiche wolde have deposed uppon a boke in the seid Court that the seid bill was in fourme forseid cancelled, and no peny lent unto your said oratour by the said Richard. Whiche proves for the instaunt labour and meanes that the seid Richard had made in the seid Court, myght in no wyse be admyttyd to depose as is aforseid. And also, gracionx lord, the seid Richard entending the utter inpoverysshing of your said oratour, hathe caused an Aldermannys commaundement to be layde uppon hym. And so lyeth in prison without maynprise, howe be it he hathe offred sufficient suyrtie to aunswer unto the said accion.

The next bill gives another example of the refusal of wager of law, not arbitrary, as the refusal appears to have been in the preceding case, but in accordance with a custom of the City of London.

\section{Wager of Law. Attaint of Jury.}

Bundle 66, No. 241.

Mekely besecheth your gode and gracyous lordship your pore oratour John Gould, that wheras one John Chamberleyn hath affermed an accyon of dette ayenst your seide oratour 
of .xIvj. $l i$. in the Shirrefs Courte of London, surmysyng by the same accyon that your seid oratour shuid have bought of the seid John Chamberleyn in Smythfeld, as moche malte as shuld drawe unto the seid summe of .xlvj. $l i$, where in dede your seid oratour never bought no such malte of the seid John Chamberleyn in Smythfeld nor in none other place, as evydently shalbe proved afore your lordship; yet that notwithstondyng, in so moche as your seid oratour may not wage his lawe in the seid accyon because of an ordinaunce and a statute had and used within the same cyte that no man that is impleted in any accyon of dette within the same cyte, yf the dette be surmysed to growe by the bying or sellyng of any maner of vetayll, shall not wage his lawe in that accyon, the seid John hath caused an enquest of the commen jurrours of the same cyte to be impanelled to passe in the seid accyon; whiche have expressely seid withoute that your said oratoure will entrete the seid John Chamberleyn and agre with hym at his wyll, they wyll passe ayenst your seid oratoure in the samo accyon ayenst all right and gode conscyence. In which case your seid oratour hath no remedy by the course of the comen lawe, forasmoche as uppon untrue verydyte yoven in London ther lieth none atteynt.

Another frequent cause of complaint was the arbitrary conduct of the officials of the court of the Marshalsea, and the illegal use of the court by the public. The court was situated in Southwark, and was intended for trying pleas between members of the king's Household by the steward and marshal of the Household; but the judges and their deputies had come to consider this restriction as merely formal, and were accustomed to enter in their records as a matter of course that both parties to a suit belonged to the Household, without any evidence, and also to refuse to defendants their lawful challenge that they, or the plaintiffs, did not belong to the Household.

An Act was passed in $1436^{\circ}$ to remedy this abuse; and previously, in 1400, the court's extortion had been checked by an Act regulating the fees. ${ }^{\text {b }}$

Here are a couple of bills, out of many others, complaining of the action of this court:

\section{The Marshalsea.}

Bundle 66, No. 217.

Mekely bisechith your goode and gracious lordship your humble supplyaunt Maister William Umfrey, studeaunt in the Universite of Oxenford, that where as he nowe late beyng in the cite of London, went from thens to Saint Georges Chirche in Suthwerk theire to speke with a kynnysman of his; and as he was comyng from thens into London thorough

a 15 H. VI. c. 1. Statutes, ii. 295.

v 2 H. IV. c. $23 . \quad$ Statutes, ii. 130. 
Suthwerk bytwene .viij. and .ix. on the clokke in the evenyng, ${ }^{a}$ one Robert Cullyng, one of the kepers of the Marchalsie there, mette with youre saide besecher and quarelled with hym, saiying that it was noo season for a man of his ordre to walke so late. And thenne and there, of his malicious disposicion without any other cause or auctorite, arrest your said suppliaunt for a suspecious man and put hym into the prison of the Marchalsie; and there without any other cause kepith hym in prison. And howe beit that youre said suppliaunt oft tymes hath offeryd to fynde sufficient suerte to answere there to suche maters as shalbe object agayn hym, yet that notwithstandyng, the said Robert wil not suffre hym to be laten to baile on lasse than he will make, seale and delyvere unto the said Robert a generall acquytaunce; and over that be bounde unto hym in an obligacion of an .c. li. that he shall nevyr trouble, sue nor vexe the said Robert for the said arest, to the gret trouble and grevous vexacion of your said suppliaunt, without any cause, to his utter undoyng without the gracious help and socour of your said lordship. Wherefor please it your said lordship to consider the premisses and to graunt a writ of corpus cum causa to be direct to the Steward and Marchall of the said Marchalsie to have the body of your said suppliauntt, with the cause of his arest, affore your said lordship in the Chauncery of our Soverain lord the Kyng at a certain day by your lordship to be lymetted, there to be examyned and ruled as conscience shall requyre, for the love of God and in wey of Charite.

\section{Bundle 64, No. 873.}

Lamentably sheweth and complayneth unto your good and gracious lordship your humble oratour William Bowreman of London, draper, that where as oon Thomas Cok, preest, of late was sued by your said oratour in the Citee of London for suche duete as the said Thomas owed unto your said oratour; the same Thomas entendyng to vexe untruly your seide suppliaunt, caused a man to come to your suppliaunt withyn London, desiryng the same your suppliaunt to come to a kynneswoman of his to Shordyche, which was seke. Wherupon your said suppliaunt so did. And when he cani to Shordyche to the seid womans hous, he founde the said Thomas Cok there; and immediatly therupon cam in officers of the Marchalsye, and there arrested your suppliant in the name of John Forster, Marchall of the Marchalsye, upon an accion of trespas. Upon the whiche arrest the said officers led your suppliant into Suthwerk, and there brought him to the said John Forster. Wherupon your suppliaunt sent into London for his neighburghs, whiche took him to bayll till the next court. After the whiche your seid oratour on Thursday last passed, cam into Suthwerk to speke with the said John Forster to understonde the cause of his arrest. And immediatly upon his comyng, he was newly arrested upon an accion of trespas atte sute of oon Piers Hous, gentleman. Upon the whiche arrest your seid suppliaunt sent into London for his neighburghs to take hym to bayll, as he did before. And when his neighburghs cam, the said Marchall wolde not take them, but said that he shuld fynde surete men of Suthwerk, the

a An endorsement shows that the bill was received on 5 th May, so that it must have been nearly dark. 
whiche your said suppliant coude not do. And how be it that every day sithen your suppliant hath labored by his lerned counseill with his wyf and his neighburghs to be taken to bayll, he in no wyse can have any graunte so to be, of lesse than he wolle make a thurgh ende with the said Piers Hous and pay hym .xx. marcs afore Cristmas day next commyng, fyndyng suerte that to do withynne Suthwerk, the whiche your suppliant can not do. Wherfore your suppliant is thrette that he shall there abyde all this Cristmas and have as many irons leyde upon hym as he may bere. Of the whiche mater your suppliant hath no remedye, but is likely to be undoon without your good and gracious iordship to hym be shewed in this behalf.

The jurisdiction of local officials was often exercised in the most arbitrary manner, and the next five bills are complaints of the unjust conduct of such persons.

\section{Maldon.}

Bundle 64, No. 905.

Mekely beseches youre good and gracious lordshyp youre poure and continuall oratoure Robbard Borogh of Maldon within the Counte of Essex, skynner, that whereas oon Richard Woode and Richarde Cessyngham of the same towne Bailes, withoute eny cause lawfull but only of very pure malice, kepe and reteyne youre seide Besecher in grete duraunce of imprisonment within the seide towne of Maldon, by cause youre seide suppliaunt hath sewed certeyn persons of the seide toune of Maldon here thys terme at the Comyn Law. The wiche seide Bailes, of ther grete simpilnes, usurpe and here clayme a previlage within the seide toune to kepe all soche persons in prison by the space of .xl. dayes that labour or attempte to sewe eny other dwellyng within the towne of Maldon; the wiche was nevyr seyne by fore thys tyme within that towne, but that they shold do and obeye all maner of wryttys and commaundementes accordyng the Kynges lawes, the wiche they utturly have refused and yet refuse, to the grete undoyng of your seide suppliaunt.

YORK.

Bundle 64, No. 864.

Mekely besechith youre gracious lordship youre pore and contynuell oratour Richard Kyrkeby, that where as he by the space of a yere nowe past of malice was arrested and putt in the Gayle of Seynt Petyrs att the Mynster gate of the Citte of Yorke, and there hath leyn evere sythen withoute eny cause shewed to hym or eny proces of accion made ayenst hym; and so he is kepte styll in prison, howe be it that he hath often tymes offered goode and sufficient suertie to be putt to bayle and mayineprise. Wherfore please it your goode and gracious lordship, the premysses tenderly considered, to graunte a corpus cum causa to be directed unto the keper of the Gayle att the gate of the seyd Mynstre, commaundyng hym by the same to bryng up the body and cause afore the kyng in his Chauncerie att a certeyn day by your gracious lordeship to be lymited. 


\section{GuildFord.}

Bundle 64, No. 1066.

Mekely besecheth your good and gracious lordship your pore oratour John Thomas, netmaker, of thage of .lx. yeres and more, that where as he before $W_{y}$ tsontyde last past, was goyng into Sussex to bere certeyn nettes to a gentilman called Cressy, which he had made for hym, was by the meanes of oon John Chamberleyn, of pure malice and evell will arrested and brought to the gaole of Gyldford. And the seid John Chamberleyn to thentent to kepe your seid pore oratour there still in pryson, wrongfully and withoute any maner cause lawfull, caused to be leyde upon your seid pore oratour suspecion of felony, by reason wherof your seid oratour was kept there in the pytte of the same gaole, where he myght neyther se hand ne fote, sith Wytsontyde forseid tyll the Sessions nowe late holden at Croydon; at whiche Sessions proclamacion was there made that if there were any man that conde or wold ought sey ayenst your seid pore oratour, he shuld there be herd. And so noo man, as they ne coude of right, there saying anything ayenst your seid pore oratour, the same your oratour was there quytte. And the seid John Chamberleyn, seyng that, yet not cessyng of his malicious disposicion, but entendyng utterly the destruccion of your seid pore oratour, and to cause hym to dye in prison, caused oon John Skynner to take an accion of trespas ayenst your seid pore oratour declaryng damages to .xl. li., where in trouth he never trespassed unto hym; to which feyned accion your seid pore oratour is not of power, ne can fynde suertee though he shuld dye in pryson, and so by reson therof was remytted unto the seid pryson of Gyldford, and there yet remayneth. Howe be it the seid John Skynner hath sith offred that if your seid pore oratour wyll gyf hym .xx. s., he shall be delyvered and goo at large; the which .xx. $s$. nor yet .ij. $s$. your seid pore oratour is not of power to pay, and soo he is like to dye in pryson withoute your most gracious lordship to hym be shewed in this behalf.

\section{ILCHESTER.}

Bundle 64, No. 928.

Mekely besechith youre goode and graceous lordship youre pore and contynuell oratour Richard Richardis, that where one John Grey, by coveyn betwixt hym and the keper of the jayle of the town of Yevechestre, hath imprisoned your seid oratour without any writte, warant or any other lawefull meanes of the lawe, and ther kepith hym still in prison and will not tell hym the cause why ne where fore. But the seid John Grey tristith to wery him in the seid prison unto the tyme that he had made a relesse unto the seid John of a certain tenement to the value of .iij. s. adjoynyng to the londes of the seid John, which hath ben in debate bytwixt your seid oratour and hym. And so he thenkith to kepe hym in the seid prison tyll that he had his entent, which were contrarie to all gode feith and conscience. 


\section{RANSOM FROM the French.}

Bundle 66, No. 365 .

Mekely besecheth your gracious lordship your contynual oratour Thomas Esthawe, that where one Edward Spencer of Hunstanton in the counte of Norfolk, now of late tyme was take owte of his howse by Frenchemen upon the see coost, and couveied from thens into the see, and ther by them kepte into the tyme that he had graunted un to them for his fynaunce on that partie an .c. $l i$. and more. For the cheisaunce of whiche fynaunce the same Ldward, by meanes of John Spencer, son to the same Edward, caused, desired and prayed your seid besecher to make shifte and cheisaunce for .l. $l i$. of the seid .c. $l i$. and the same Edward shuld truly therof your seid besecher recompence and be saved harmeles. And for as moche as your seid besecher, havyng gret pety and beyng sory of the gret losse, and also for good wille and love that he had to the same Edward, he at the desire, request and prayer of the same Edward by the meane of the seid John Spencer his sone, whent with the same John to one Edmond Pepyr than dwellyng in Lynn in the same counte of Norfolk, and ther cheivyst and borowyd of hym for the helpe and relief of the seid Edward .l. li. of mony. And therfore at the request of the same John was bounde with the seid John in an .c. li. to the seid Edmond, whiche obligacion was redde onto the same Thomas that the seid obligacion conteyned this condicion folowyng, that is to say;--that if the seid Thomas and John pay not to the same Edmond Pepyr .l. 7. . by the fest of Cristmesse last passed, that thanne the seid obligacion of an .c. $l i$. shuld be good and effectual, and ellys it shuld be voyde. Your seid besecher at that tyme of the makyng of the obligacion, beyng a lay man and not lettered, supposyng and trustyng that the same obligacion had be indosed with the seid condicion, where it was not indosyd with any condicion, sealed the same dede, trustyng also verely that the seid Edward and the seid John Spencer his sone wolde have savyd your seid besecher harmeless of the seid .l. $l i$. Ther hath the seid Edward and his seid sone by covyn, sotylte and ymaginacion had atwene them and the seid Edmona Pepyr, caused and steryd your seid besecher to cum to the seid towne of Lynn with a gose and a capon to dyne with the same Edmond Pepyr, and to intrete hym to have lenger days of payment of the seid .l. li.; but the verry intent and covyn had bytwene the seid Edward and Edmond was that your seid besecher, as sone as he cam to Lynn, shuld be arested for the seid dute. And therupon your seid besecher, havyng no knowlage of the seid covyn, crafte and ymaginacion, cam to Lynn aforeseid to thentent to have intreted the seid Edmond Pepyr for lenger days of payment for the seid .1. $l i$. And the same Edmond at the same tyme caused your seid besecher to be arested in the seid towne of Lynn by a pleynt for the seid .c. li. at the sute of the same Edmond, intendyng veryly to have recovery ageyn your besecher of the seid .c.li., whereas the verry dute is but.l. $l i$. And if your seid besecher shulde plede any ple in voydance of the seid obligacion by the mater afore alleged or any other wyse, the seid Edmond is of so gret myght, poer and so gretly favord and acqueynted withinne the seid towne of Lynn, that what so ever ple were pleded for your seid besecher in this seid mater, 
it wer like to be tryed ageyns hym withowte any consideracion of trowthe to be had in that behalve; whiche were and uttyr distruccion and undoyng of your seid besecher. Please it your good and gracious lordship to considere the premisses, and how that by crafte, covyn and sotyl ymaginacion had betwene the seid Edward Spencer, for whom your said besecher was bounde, and the seid Edmond Pepyr, to whom the seid obligacion was made, by the whiche thei bothe intended to the uttyr distruccion of your seid besecher, to graunte a wrytte of corpus cum causa to be directed to the baylyve of the right reverend fadyr in God, James bysshop of Norwiche, of his towne of Lynn, and to Richard Herde keper of the jayle of the same bysshop there, commaundyng them by the same wrytte to have afore our Soverayn lorde the Kyng in his Chauncery at a certeyn day by your lordship to be lymytted, as well the body of your. seid besecher as the cause of his arestyng and detencion in pryson, and that alle the premysses in this courte may be duly examyned; and ther upon swiche reule and direccion to be had as lawe, reason and consciens requyrith. And that for the love of God and in wey of charyte. And your seid besecher shall ever pray to God for you.

One of the historical points, which I believe children are taught at school, is that trial by jury is the palladium of English liberty. The common folk of the fifteenth century seem, however, rather to have regarded a jury, especially a petty jury, with dread, as one may infer from the following bills.

\section{JURY.}

Bundle 64, No. 897.

Right mekely besechith your gracious lordship your pore suppliant Henry Saunder of London, milpacker, that wheras one Thomas Dyconson, a keper of one of the unclenly howsez in the othir side of Temmesse, diverse tymes bothe in the cite of London and at the Toure, hath of his grete malice trobolid, swed and arrested your said supplyant by dyverse fayned accions ayenst trowth and conscience, in which the said Thomas cowde never prevayle by the lawe, to the grete hurt and grevouse cost of your said supplyant; the said Thomas, not sesyng of his malice, nowe late your saide pore oratour beyng in Sowthwerk abowte his besynes, causid hym to be arrest in to the Bisshop is preson of Wynchestir by dyverse fayned accions of dett and trespasse, and byn at an issue, tho that ben inpaneld in the enquest ben occupyers and kepers of such unclenly and defarny places as the said Thomas is, which purposyn ayenst all conscience to cast youre said poure oratour in so grete damagez that he shall never be abull to bere hit, unto the uttermost undoyng of your said suppliant withoute your gode lordship be unto hym in this behalf shewid.

\section{Bundle 67, No. 104.}

Mekely besechith your gude lordship Mathew Petit of London, merchaunt, that where one Johane Gybson, wyffe of one Robert Gybson, late cam to your besecher, beyng gret with VOL. LIX. 
childe and sore betyn and hurt, and so sore strykyn upon hir right ie that the blode issued owght, the same Johane then seyng to youre seyd besecher that without she myght have sume eyd and socur of hym, she wer uttyrly distroyed, and seyd that hir husbond was in prison in Ludgate and condempnyd to divers men in gret summes of money, and she seyd fardirmore that hir husbond had made a deid of gyfte of all his goodys to one Thomas Gybson, by mene wheroff she had nothyng to lyf by, and seid that she had bene with hir husbond in Ludgate, shewing to hym hir gryffe, and for that cause hir husbond, as she seyd, had so strykyn hir and hurt hir. And the same Johan seyd and deposid with great othis that she had not one peny to eyde hirselff with. Wherfor she desiryd your seyd besecher in the wey of allmes and charite to help hir, that she myght be relevid with lechecraft, and also to gyff hir mete and drynk. And jour besecher, beyng mevid with pyte, seyng the seid Johan gret with childe and sore hurt and utturly cast into that lamentable mysery of lakkyng hir sustenaunce, and also for concideracion that the same Johan was and ys cosyn to the wyffe of youre besecher, therfore he of very pyte, seyd to the seyd Johan that yf she wolde goo to a surgeon namyd Sabastian, he shuld releyff hir with his conyng of surgeonry and it shuld cost hir no money; and ferther seyd that forasmuch as she, the same Johan, was a mannys wyffe, therefor he wolde not hir resceyve into his howse, nor kepe hir in any wysse, savying onely he seyd that rathir then she shuld peryssh for defawte of mete and drynk, at sich tymes of neid as she wolde cume to the seid house of your besecher and ask mete, she shuld have it for the luffe of God. And it ys so nowgh, gracius lorde, that the seid Robert Gybson, husbond of the seid Johan, of his malicious disposicion withowte colour of cause resonabull, hath affirmyd a pleynt of trespas befor one of the Shiriffes of London, and by force therof causid your seid besecher to be arestid, imprisonyd and sore vexit, and hath surmisid that your besecher certen day, yeir and parich in London, with force of armys touk and led awey the seid Johan, wyffe of the same Robert Gybson; and alsu surmysid that your besecher touk and bare away godis and catellis of the same Robert Gybson to the value of .xy. li. To the which your besecher pleatid acordyng to the truyth, as God knowyth, that he was not gilty, for he never medild in any wyse with the seid Johan, wyffe of the seid Robert, but onely as it ys befor shewyd by your seid besecher in this bill. And the seid Robert Gybson by synestre meanes of labur hath causid men of litill substauns and havir at his owne denominacion to be impanellyd, the whiche be cause of speciall aqueyntawnce, favour and allyaunce that they owe and be of to the seid Robert Gybson, wil hir no evidens to be gyffyn to them for the parte of your besecher, and also seid that they wil nevir giff credens to the seyng off a merchaunt straunger in no accion wheras a Inglyshman is party. Wherfor your besecher, beyng a merchaunt strawnger and born beyond the see, by mene of the seid jurours, which neyther dred God nor the offens of perjure, shall be condempnyd agenst all gode conciens and withowt remedy by the comyn lawe, forasmuch as ther lith non atteynt upon untrewe verdit gyffyn in London.

The next bill contains a similar complaint of the absence of attaint in London, but the interest of the bill consists in its description of medieval sport. 


\section{Horseracing.}

Bundle 67, No. 49.

Mekely besecheth your good and gracious lordship your daily oratour William Whytyng of York, dyer, that wher abowt Whygtsontyde last passed at Hull in the counte of York, oon John Martyn of London, draper, and Miles Bysney of the same, covenaunted to gedyr that what time they shuld come .ij. myles and a halfe from Yorke to a crosse called Grymston Crosse standyng in the right waye from Hull to York, .ij. childern shuld be sette uppon their .ij. horses, and oon John Nicholson shuld sette forthe the horse of the seid John Martyn with a child syttyng uppon the same horse be the space of a furlong, and oon Thomas Spycer shuld set forth the horse of the seid Milys by the same space with an other childe sittyng upon that horse; and from thensforth the seid .ij. childyrn shuld ryde towardes York as fast as they cowed, kepyng alwey the right weyes towardes York; and $y f$ the horse of the seid John Martyn so set forthe, bothe horses kepyng alwey the right cowers, come souner to a mylne hill standyng in the high weye but half a mile from York than the horse of the seid Miles, than your seid suppliaunt shuld delyver to the seid John Martyn .xxx. s. which was leyed in the handes of your seid suppliaunt at Yorke aforseyd by the seid Miles to the same entent, and elles your seid suppliaunt shuld delyver ayen the same .xxx. s. to the seid Miles. And be as moche, good and gracious lord, as that the seid John Nycholson, takyng upon hym to sett forthe the seid Miles horse, which shuld not have medelled therwith but oonly with the horse of the seid John Martyn, evyn in the settyng furthe cautelously turned the horse of the seid Miles owt of his waye towardes the sowth into a falowe feld, and ther the same horse overthrew the childe that sate upon hym, and so ranne forth sowthward more than a myle owt of the hye waye, and so kept no right cowers towardes York; all such persones as were there indifferent demyd by their conscience that your seid suppliaunt owt of verry right for to delyver ageyn the seid .xxx. $s$. to the seid Miles, and so he ded, as the same Miles ys redy to wytnes at all tymes whan he shall be called therto. It is so, good and gracious lord, that your seid suppliaunt come but late to London for to bye certeyn ware there, and the said John Martyn hath caused hym to be arrested ther in one of the Shirrefs Counters upon an accion of accompt, supposyng that your seid suppliaunt at London in the parisshe of Seynt Sepulcrus shuld have resceyved of hym .xxx. s. to yelde hym acompt of, purposyng be the mene of .xij. of his neybours be hym specially embrased and to whom your seid suppliaunt utterly unknown, to cause your seid suppliaunt to be condempned unto hym in the seyd.xxx. s. ayenst all right and good conscience. Wherfor your seid suppliaunt mekely besecheth your good and gracious lordship tenderly to consider the premysses, and how that the .xij. men of London owt not to medle with foreyn maters by the lawe, and yet oft tymes they doo, and the partie agenst whom they passe ys without remedy at the comen lawe bycause ther lyeth none atteynt in London; and also how that the seid John Nicholson, whiche sett the seid Miles hors owt of 
his right cowrs at the settyng forth of the same, was pryvyly of covyn with the seid John Martyn, and shuld have had halfe the seide .xxx. s. yf the same John Martyn had goten theym, as your seid suppliaunt can sufficiently prove.

JURORS SUPPLIED with FoOD.

Bundle 64, No. 269.

Humbly besechith your gode lordship your poure oratoure Guy Hadam, that where one John Aleyn of London, brewer, and another woman at the sight on Seynt Petir is nyght last past in Chepeside of London had bothe ther purses cutt, wher upon ther was a grete rumor and noyse among the peple abought them. And your seid suppliant as he cam by, stode and herd the seid rumor and noyse of the peple, and as he stode under his fote fownde the womans pursse, and toke it upp and hild it upp on heght in his hande over his hede and shewed opponly that he bad founde it. And incontenent the seid John Aleyn toke your seid suppliaunt and seid without he wold delyver his purce as well as the womans, he wold bryng hym to the Countre. Whereuppon youre seid suppliaunt was serchid, and they cowde fyude no purce nor knyf nor any other suspecious poynt uppon hym. That nott withstandyng the seid John had hym arrested and hath summoned suche an enquest that .iij. of the same undertoke to rewle all ther felowship. And they had with them in the rownd house datis, reysons of currannce and other spyces att the cost and purveyaunce of the seid John Aleyn, as it shall be proved before your lordship, and made all the remenaunte of the enqueste to feynte for defaut of sustenaunce that without they had seyd as they .iij. did, they had ben like to have dyed. Wheruppon they vave ther verdite, and cast youre said suppliaunt in .v. marcs, contrary to all trough and conscience, and to the utter undoyng of youre seid suppliaunt without it may please youre gode lordship, the premisses considered, in so moche as jugement theroff is nott yett gevyn, and also that the seyd $\mathrm{J}_{\mathrm{O}} \mathrm{hn}$ hath caused an alderman of the seid cite to ley his commaundment uppon your seid suppliaunt, so that howe be it your seid suppliaunt hath many tymes offered suffycient suerty, yett in noo wise he can be lettyn to bayle, to graunt a corpus cum causa to be derect to the Sheriffes of the seid cite, etc.

JURY.

Bundle 67 , No. 154 .

Lamentably compleyneth unto youre goode and graciouse lordshipp youre pouer oratoure and chapleyn, Sir Thomas Bateman, preste, that where as one Peers Fidyll of London, pulter, of late brake certey $n$ hegges and gardeynes of youre besecher atte London, and there bare awey asmoche frute to the value of .xx. $s$. and more; for the whiche trespas so done youre 
besecher toke an accion accordyng to the lawe in the seid Citee afore the Sherreffes of the same. And when the seid Peers was arested and lete to bayle, and the contre summoned apon the same, the seid Peers by thadvise of certeyn of the queste so summoned toke an accion of trespas ayenste youre besecher to the damages of .xxvj.li. there, surmysyng by the same that youre besecher shulde make asaute apon hym and sore bete hym and wounded; and apon the same purposeth by the supportacion and promise made by the petye jurrours of the seid Citee, to condempne your besecher. Where as summe of the same have seid byfore sufficient profe, seyng these wordes, "Peers the preste hathe money ynoght, and he may well pay, and therfore doute not but wee shall geve hym a lyfte." And so youre besecher ys like to be condempned in the seid .xxvj. li. by the myght of the seid queste, where youre besecher never trespassed ayenst hym nor none of his, to the uttermost undoyng of youre besecher ayenst all right and goode conscience.

If this tale be true, it shows that a priest was considered a proper victim for extortion. Evidence of a similar feeling is afforded by the three following bills.

\section{Escheator's Extortion. Priest.}

Bundle 66, No. 417.

Mekely besecheth your good and gracious lordship your dayly oratour John Towker, that wher oon John Garnesey, late servaunt to the Eschetour of the counte of Somersette, subtilly ymagynyng as depute and servaunt to the seid eschetour, to gette and rekyver extorciously of your seid suppliaunt a summe of money, came to con William Towker, preest, broder to your seid suppliaunt, seiyng to hym that he was owtlawed. For the whiche cause the same John Garnesey seid that he, as depute and servaunt to the seid eschetour, wold sease all the goodes belongyng unto the seid William Towker, preest, as goodes eschetid to the Kyng by reason of the seid outlawry, on lesse then he wold geve to hym a reward of .xl. $s$. To the whiche the seid William 'Towker aunswered seyng that he never gaffe cause to eny persone to commense or sue eny accion ayenst hym, nor never had knowledge of eny owtlawry to be ayenst hym pronownced; to the whiche the seid John Garnesey aunswered, seiyng that he knew seuerly that the same William Towker was owtlawed; and furthermore promysed to the seid William 'Towker and to the seid John Towker your besecher, that if they wold be bounden to hym by their single obligacion in the summe of .xl. s. to be payed to hym at a certeyn day, that than he wuld surcese of season of eny godes of the seid William Towker; and also promysyd upon his feith that if he brought not to the seid William Towker and John Towker before the day of payment conteyned in the seid obligacion, a copy of the seid owtlawrye, by the whiche it shuld playnly apere that the seid William Towker was owtlawed before the makyng of the seid obligacion, that then he wuld never clayme eny duete by the seid obligacion nor them vexe by colour of the same. 
And the seid William Towker and John Towker, gyffyng trust and confidence to the promyse and seyng of the seid John Garnesey, bowend them selfe jontly and severally to the seid John Garnesey in the summe of .xl. $s$. And afterward the seid John Garnesey brought no copy of the seid owtlawry unto the seid William Towker and John Towker nor either of them, nor none cowde bryng; for as moche as the seid William Towker at the tyme of the makyng of the seid obligacion nor before was not owtlawed. The whiche not withstondyng, the seid John Garuesey contrarie to good conscience hath commensid an accion of dette before the Kynges justice of the Commen Place uppon the seid obligacion ayenst your seid besecher, and ther entendeth to condempne your seid besecher contrarie to rightwisnesse and contrarie to feith and promyse by the seid John Garnesey in forme forseid made; of the whiche your besscher can no remedie have by the comen lawe.

\section{HEREFORD.}

Bundle 64, No. 827.

Humblie besecheth your good and gracious lordshypp your humble and pore oratour Nicholas Coke, chapeleyn, to consyder that wher your seid suppliant was falsely enprisoned by one Thomas May, late mayr of the cyte of Herford, and by hym styll kepte in prisone tyll he had made a fyne wyth hym of .xl. s., for the wheche wrongfull enprisonment your seyd oratour hath a byll ageynst the seyd Thomas May in the Kynges Escheker be for the Barons of the seyd Escheker. And for cause that your sayd oratour pursuyth ageynst the seyd Thomas May accordyng to the ordour of the lawe, the sayd Thomas May come to your seyd oratour au Herford and seyd that he wolde spend .cc. $l i$. for to do hym a evyll torne. And therupon by confort of the seid Thomas May, one of his servantes callyd Richard Court made a fray uppon hym, and drewe a swerde uppon hym and wolde had a myschevyd hym had not other men ben; and also manased hym that wher sum evyr he mygth mete hym, he wolde bete hym.

And therupon, for fere of bodely harme, your seyd oratour toke suerte of peas ageynst the seid Richard Court, and causyd hym to be arestyd and for to fynde suerte to kepe the peas. And by cause of the weche arest the seid Richard Courte, by the exortacion of the seid Thomas May, hath affermyd a pleynt of fals inprisonment ageynst your seyd oratour be fore one John Tayle, now beyng mayr of the sayd cyte of Herford, and hath declared to his damage of .1. $l i$. Wher uppon your seyd oratour was compellyd to answer, and he cowde have no maner of concell for no maner of money to be wyth hym, nor the Court wyll nogth assigne hym none by no maner of meane, the wheche ys contrary to lawe and consyens. And also $y t$ was openly seyd by the town clerke ther "that he that presumsth for to sue one that hath ben mayr ther, he owth to have no consell." And theruppon your seyd oratour understode nogt what to do, but as a man unlernyd pledyd nogt gylty, wher yf he had had consell he mygt have justified hyt accordyng to the lawe. So for defaute of consell and also by the especiall labour that the seyd Thomas May makyth, and also the mayer nowe beyng, and 
suche as have ben mayers take party ageynst your sayd suppliant, your seyd suppliant ys lykely to be condempnyd contrarye to the lawe and good conciens wythe owte your good and gracious lordschyp be schewyd unto hym on thys behalfe.

\section{Clekgy.}

Bundle 64, No. 1067.

Humble besechith your lordship your pore chapellaynis and oratours Sir Nicholas Whyte, Sir Martyn Darcy, and Sir Robert Brenan, prestis, that where as they on Friday nyght last past abowte .vij. of the clok sat in an honest house called "The Rose" in the Old Jury at London drynkyng a peny worth of ale, they thynkyng no harme, and were in Goddes pease and the kynges; whereuppon there was to or thre ill disposed persones, which were not at that tyme well advysed, overthwartely quereld with your said oratours, and so multiplied there unsettyng and shamefull langeage, thorowe whiche they wold have bettyn and wondyd youre said oratours, ne had thei not defend themselfe and skapid frome them and toke their chambres. Whereuppon they arraysed ther neyghbours, and wolde have brokyn upp the dorres of their said chaumbres, without your seid oratours had not com downe unto them, and there they browght your said oratours withowte any cause resonable unto the Countre and kepe them there all nyght, and yet doth; and also hath cast them in the fray. And morcover hath surmysed divers accions of trespasse ayenst them, and layde apon them an Aldermannys commaundement, by force of which they may not go at ther liberte to labour for themselfe; howgh be hit your said oratours han offred ryght sufficient suertes, and can in no wyse thereto be amytted, contrari to trowght and conscience, and to the grette hurt of your said pore chapellayns and oratours without your speciall lordship be unto them in this behalfe shewid.

\section{Leasingham.}

Bundle 73, No. 54 .

Shewith yow William Pheljpp, knyghte, on the parte of oure lord the kyng, that where as Nicoll Besonthyn, vickery of the chirche of Lesyngham in the Counte of Lincoln, Edmund Baxster of the same, and other parachones of the same toune, and tenauntes to the sayd William Phelypp, the .xvj.th day of Maii last passyd, wente procession aboute the boundes of the sayd toune liche as hath be usyd before, to praye for the peas and the good spede of oure soveraign lorde; ther come John Harvy of Evedon in the countie of Lincoln, swyer, Richard Hert of the same toun, laborer, John Cusson of the same, husbondman, Adam Cusson of the same toune, husbondman, Thomas Gelle of the same, husbondman, John Louthe, yonger, of the same, laborer, John Gelle of the same, Robert Hornblynke of the same, husbondman, Rauffe Kyrkeman of the same, husbondman, Henry Smyth, of the same, 
smyth, and other, with gret aray with palettes, haburjones, bowes, arwes, axes and gleyves as men of werre and riottours, and in the said vicary and parachones mad assaut and the crucifixe pulled don, seyng yf they went any further procession, that thei shulde slei them. For fere of which the sayd vicary ner parachones durst not at that tyme ne sithyn goo in procession, ${ }^{a}$ leche as they have usyd tofore, the which is odyouse example. Please yt to yowre gracyouse lordship to grauntte writtes subpena directe to the sayd riottoures to appere aforn yow, and to chastise them so for this sayd ryotte, that other have now exemple to make swiche riotte. For the love of God and in the weye of Charite.

The following are specimens of bills asking for relief which the complainants believe that they cannot obtain through the common law.

\section{A Father's Will.}

Bundle 66, No. 454 .

Mekely besechith your humble oratours John Besynbe and Isabell his wyfe, the eldest doughter to Sir Hugh Welughbe, knyght, and to Dame Marget his wyfe, summe tyme dwellyng at Wollaton in the Counte of Notyngham, that where in the lyfe of the seid Sir Hugh the seid Isabell and Philip Boteler, then hir husbond, in a tyme come to Wollaton beforeseid to thentent to se hir seid fadir and modir, and ther taried .iiij. or .v. dayes. And or they departed thense, the seid Sir Hugh called unto hym the seid Dame Marget his wyfe, and the seid Isabell and dyverse other of his children and servauntes then beyng present, and there declared afore theym howe that he was most specially byholden to the seid Isabell and had founde more kyndnes in hir than in all the children that ever he had, wherfore he ther stretly willid and charged that the seid Isabell shulde have asmoche of his goodis as eny doughter that he had unmaried, which was certeyned by his will in writyng; and theruppon charged his wyfe, the seid Dame Marget, that she shuld delyver hir suche goodes after his dissease as she wold answere byfore God atte dredefull day of dome, saying thus to hir, "I shall leve enough to you to performe my will." Saying also to the said Isabell, "Doughter Bele, I charge youe on my blessyng and as ye will answere before God and the devyll, that ye clayme it and aske it"; with many other circumstaunces whiche shalbe declared to your lordship hereafter. And anon after the seid Isabell and Philip Boteler, then hir husbonde, departed from thens home in to his contre. And within fewe dayes after the seid Sir Hugh made the seid Dame Marget his wyfe his executrice and died. After whose discease within fewe dayes after, the seid Isabell came to the seid Dame Marget hir modir and remembred hir of the seid Sir Hugh hir fadirs will declared in hir presence and others that she knewe right well. Hir seid moder answered and seyd, "Doughter, I knowe it well. As sone as I have maried your bredern and susters, ye shall have your parte according to your fadirs will;" as she in lyke wyse dyverse tymes sithen

a This disturbance appears to have grown out of some dispute about parish boundaries. 
hath seid in presens of dyverse persons yet redy to recorde the same; and specially the .viij. day of August in the .xxxvij. ${ }^{\text {th }}$ yere of Henry late in dede and not in right Kyng of Englond, at a maner of the seid Dame Margaretis called Middilton Hall in the shire of Warwik, where the same Dame Marget seyd unto the seid Isabell of hir owne mocion withoute eny remembraunce afore had, seid thus .ij. tymes. "Doughter Isabell, als sone as I have doo with the mareyng of your suster Eleanore and your brother Rauffe, in good feith ye shalbe served of all that was your faders will and charge"; as dyverse folkes ar redy to recorde the same. But thus by such wordis the seid Isabell many yeris hath be delayed and yet is, and hath suffred for displeasur of hir seid modir, the which she may susteyne no lenger. And nowe late the seid Isabell and hir husbond, your suppliaunt, have required the seid Dame Margaret to performe hir husbondes will accordyng to the premisses, and that to do she utterly refusith, and puttith it in delaye; wherin your suppliauntes can have no remedy by the course of the comen lawe, to the gret hurte and losse of your seid suppliauntes in lesse your gracious lordship be shewed to them in this behalfe.

\section{Detention of Deeds.}

Bundle 64, No. 556.

Sheweth unto your good and gracioux lordshipp Robert Draycote that, where he is seased of a mees with thappurtenaunce in Chelmerdon in his demeane as of fee, it is so, gracioux lorde, that divers dedes and evydencys concernyng and apperteynyng to the seid mees be comyn to the handez of oon William Bayly. And howe be it, gracioux lord, that your seid oratour hathe required delyvere of the seid evydences of the seid William, yet that to do he at all tymes hathe refused and yet dothe, contrarie to reason and good conscience. And in so much as your seid suppliaunt knoweth not the certeintye nor nombre of the seid evydences, nor whether they be enclosed in bagg, boxe sealed or chest loken, he can have no remedy by the common lawe.

Bills concerning detention of deeds are common, and usually contain this last clause.

Perhaps some here may remember in Fielding's Amelia, that when Dr. Harrison has captured Murphy, who had misappropriated title-deeds, the magistrate to whom he applies for a warrant says, "If the deeds were in a box, it would be felony to steal the box." a

In the following cases the poverty of the complainants is the cause of their application to the Chancellor.

a Book xii. cap 7, vol. ix. p. 342 .

VOL. LIX. 


\section{Action of Trespass against Children.}

Bundle 64, No. 912.

Humblie besechith your gode lordship your pore childern and oratours, Richard Desford and John Desford, that where as one Richard Bolte of London, pewterer, of great cruelte and malice hath your said oratours arrested in the Countre of London upon a accion of trespasse, they beyng within the age of .xij. yere, that they shuld with force and arms, with knyfes and other wepon, brake the hous of the said Richard Bolte, and bete .ij. of his servaunts to the hurt of .xxvj. $l i$; ; where in dede of verrey trowght they never entird in to the hous of the said Richard nor never bett none of his said servauntez, save onely one of your said oratours cam unto the hous of the said Richard Bolte, and be the deliverance of one of his servauntez had delyverd a quarte pott belongyng unto the fader of your said oratour, for which after of his malice made his said servaunt to quarell with one of your said oratours, by which iche of them smote other with ther fistes, and no nothir harme done. And for this cause, by his labour, knowlich and myght, ayenst all trowght and conscience, wold cast your pore childern in the said some of .xxvj. $l i$. for the valewe of a quart pott of .vij.d., ayenst all right and conscience and to the grete hurt of your said childern.

\section{The Rood at St. Paul's.}

Bundle 73, No. 169.

Besechen mekely your pouere oratours John Paunton of London, tailor, and Johanne his wyf, graciously for to considre that John Rider, clerk, gaf to Amy I'unbek and to the said Johanne and to here heires a mees and certein land, with the appurtenaunce, in the toune of Barghwam in the counte of Suffolk; by vertu of the whiche gyfte thay bothe weren seised of the said mees and land, and the forsaid Amy contynued here possession terme of here lyfe. And a lytill tyme before here deth she committed the kepyng of the said mees and land to John Luke, upon high trust that she hadde in hym, and delyvered to hym here godes and catall and here evydences beyng in the same mees, with the keis of the dores of it, sally for to kepe to here usee and to the usee of here said doghter. And after that the said Amy come in pilgrimage to the Rode of the north dore in Paules, and also for to see and visit your said suppliantes. And afterward the said Amy fell seke and deid in Fletestrete. And the forsaid suppliantes han ofte tyme required the forsaid John Luke for to make livere to hem bothe of the forsaid mees and land and of the dedes and evydences of all to have to hym as right and consciens wold, but the said John Luke denyes and refuses for to make lyvere to the suppliantes aforsaid of the said mees and land and of the dedes and evidences of it, to grete harm and lost to the same suppliantes. Wherefore like it to youre most gracious lordship to send after the forsaid John Luke by a writte subpena for to appere byfore yowe in the Chancery at a certein day, there to be examyned of these materes, and to 
doo right to youre said suppliantes as gode faith and concians will, at the reverance of God and in the way of charitee, consideryng that they arn soo powere that they may noght suee the commun lawe for theyre righ in that partee.

\section{MARRIAGE.}

Bundle 66, No. 317.

Sheweth mekely beseching unto your good lordship your poure oratrice Alianore Lunte of Moche Waltham in the Shire of Essex, wedowe, that where diverse communicacions were late had and moved of mariage unto your seid oratrice by oone John Mynton of Berkyng in the seid shire; wherupon the same your oratrice, of grete trust whiche she had in the same John, and at his often and many desires to thentent of matrimony by hym feithfully unto her promytted, delivered unto the same John the substaunce of all her goodes, that is to sey .c. $s$. in money and other diverse goodes to the value of .xx. marcs, and diverse and many evidences concernyng the lond of your seid oratrice.

And after that the seid John had the possession of the seid money, goodes and evidences, he knowyng well the same to be the substance of all the goodes of your seid oratrice, than kepte and yet still kepeth and reteigneth all the same goodes, and denyeth his promys aforeseid, and in any wise to restore unto her the same goodes hath uttirly refused and yet refuseth, as a fals and deceyvable dissimuler, neither dredyng God nor the Kynges lawes. For as it is seid the same John hath a wyff beyng alyve, and hath not oonly thus deceived your seid oratrice, but diverse other in like fourme afore tyme. And by such sinistre meanes and labour of the seid John, affirmyng and callyng hymself a sengle man, and assuryng hymself by large promyses and othes to take to wyff your seid oratrice and her lawefully to wedde, your seid oratrice is thorough trust of the same uttirly undone, and is not of power to sue her recovere by way of accion after the cours of the comen lawe of this lond for grete poverte, her seid goodes thus beyng oute of her possession; so that she is withouten remedy but if your especiall good lordship to her be shewed in this behalf.

This case of breach of promise might belong to any age, but here is an account of the manner in which our rude forefathers sued their intended brides, which happily is quite out of date:

\section{MarRiage.}

Bundle 64, No. 419.

Mokely scheweth unto youre good and gracious lordship, Herry Sumpter late of Copforde in the counte of Essex, husbondman, that where he is attached be the body in 
the toune of Colchester to answere to a pleynte of dette affermed ageyne hym before the balies of the seid towne of Colchestre in ther Mote Halle, at the sute of Edward Smyth, Stephen Smyth and Thomas Kechyn, the yonger, upon an obligacion of .xl. li. It is so the seid Herry Sumpter hath a doughter called Agnes, now of the age of .xvj. yere, the wich Agnes, whan she was not full .xij. yere olde, was be the seid Edward and other riotous persones taken away from her said faders place at Copforde aboveseid, upon the Trinite Sonday, and sette uppon a horsse agayne her wille behynde one of the seid riotous persones, and ledde on to the place of the fader of the seid Edwarde, the wich was .vij. myle from her seid faders place, and there thei wolde have hadde her to have made a contracte with the seid Edward to have hadde hym to her husbond; unto the wich she wold not agree nor yet wulle. And so at that tyme they lette her departe home agayn unto her faders place. And from that tyme tyll Marche laste paste, the seid Herry and Agnes have be contynually trobelid be the seid Edward and his frendys, in so moche that she was fayn to departe into the counte of Norfolke, and there dwelte a yere and more. And the .xx. day of Marche laste paste, the seid Edward and Thomas Kechyn sent for the seid Herry Sumpter and willed hym to be bounde to them in a obligacion of .xl. $l i$., to this entente that his seid doughter shulde be putte in feer that if she wold not have the seid Edward, she shuld no oderwise knowe but that her seid fader shuld lese the seid .xl. $l i$. be the seid obligacion, promyttyng hym he shuld nevyr be hurte be the same. And the seid Herry, trustyng ther seid promissez, of truste delivered it them to the entente rehersed. And that notwithstondyng, the seid Agnes wold never agree to the seid mariage. And the seid Edward, seyng he cowde not opteyne his purpose in the seid mariage, contrary to his seid promyse, hath affermed the pleynte agayn the seid Harry as is rehersed, in his name and otber before the balies of Colchestre, as is above rehersed, uppon the seid obligacion of .xl. $l i$. And there he is like to be condempned without the aide and comfort of your good lordship. And sith the seid Herry hath no remedy be the comen lawe of the lond, to graunte a certiorari, etc.

The next two petitions refer to houses of religion. In one, the complaint is against an abbey, in the other, a prior, who is a bad disciplinarian, appeals for help in keeping his monks in order to the Chancellor, on the ground that he has no ordinary within the realm of England to whom he can complain.

\section{Pershore Abrey.}

Bundle 73, No. 44.

Beschit mekely youre and continuall orature Robard Neweman, that where as the seyd Robard maad a bargayn with William, late abbot of Percyore, and John Cheltenham, priour of the same place in the countee of Wurcetour, to make a vowte in the bowke of the cherche of Percyore aforeseyd, for a certeyn summe of money and for an annuite of .xx. $s$. and a 
gowne yerly terme of hys lyve under the covent seall, as hyt more playnly aperyth by a bylle endentyd maad betwext youre seyd besecher and William, late abbot of the seyd plase. And youre seyd besecher hath wyll, truly and saffyciauntly maad the seyd vowte; and to make, seell and to delyvere to youre seyd besecher hys dede of annuyte acordyng to hys promyse, of .xx. s. and a gowne terme of the lyf of your seid besecher, Edmond Hert, the abbot that nowe ys, and the seid priour, utturly reffusyn, to the grete hurt and undoyng of youre seyd besecher. Plese hyt your gracius lordschep this grete preiuise a and wronges done to your seyd besecher, and he with owte remedye atte the comyn lawe, and to graunt hym wrettes ycalled sub pena dyrectyd to the seyd abbot and priour to a peer afore yow in the Chauncerye atte a certeyn day by yow alymytyd under a certeyn peyne, for the love of God and in way of Charyte.

\section{Holy Trinity Priory, York.}

Bundle 47, No. 256.

Humble shewith unto youre lordeship youre pore oratour, Robert, Priour of the Holy Trinite of Yorke, where Dan Robert Marshall and Dan John Garland, comonis of the said priore, that as where the said Dan Robert and Dan John jontely and severally diveres tymes and ofte, contrary to theire profession, have offended and trespassed in disobedience, and wold not obey ne kepe the rule of religion, bot ofte tymez haffe goune out of the place late and arely without licence of any persone, in ley clothyng with basselerdez and other fencible weppen, jettyng be nyght as well within the Cite as withoute in unclene conversacion with wemen and other menys wifez, to grete sclander of the place. And fortermore, the said Dan Robert and Dan John, uppon the morn next after the Assumpcion of Oure Lady at nyght, arrayed theym fencibly in seculer clothyng and went oute of the place betwix .ix. and .x. of the cloke in the nyght unto a place withoute the cite called Seynt James Leyes, and ther they mette with oon John Dewe, a servaunt and prentese at the marshall crafte with oon Adam Hudson, an honest man of the Cite. And ther the said Dan Robert and Dan John Garlond chalenged hym, and with theire baselardes gaffe hym diveres strokes in so much that they had almoste stryken of his lyft honde, as hit is yet to shewe and wolle be to his deyng dey, as the same John Dewe deposed affore youre seid suppliant and other bredren of the place, Thomas Neleson, Richard Claybruk, William Wryght and Nicolas Halyday, Sir Thomas Gyles and other worshipfull men of the Cite. Furthermore, the said Dan Robert Marshall had a manes wiffe in his selle within the dortour of the convent of the same place certeyn tymes, wich woman is called Maude Stanes; her husbond is a glasyer. And whan $y t$ was knawen, the same Dan Robert removed her in to the stepyll of the churche, and ther was she takyn oute. Hee not remembryng that shame, wold not leve ther with but after contynually acompayned hym with her and other evill named and vicious wemen with oute

a Prejudice. 
the place in suspect places by nyght, not kepyng his observance and tymes of devyne servicez within the said churche as a man of religion, but continuelly hantyng thise and mony other myschevous reules bothe be nyght and day, to the grete rumor and sclaunder of the place. Also the seid Dan John Garland contynuelly accompayned hym in knowlage of syn with a yong woman dwellyng with William Marshall, a rendour within oure place. Wherfore he was charged to lefe her feloship and not to come where she were by the vertue of the obedience, but he presumptuosly brake his obedience; for dayly and nyghtly wold he be with her at unlawful tymes and places unto tyme she was aroyded out of the place. And than was she abydyng at oon Nicolas Halydayes, and the said Dan John by his sotell craftes oft tymes at myddes of the nighte wold open the chirch dores and go forth and clymbe over the walles of the said Nicolas Halydais place, and be with her at his pleasure, ay when he wold. Wherfor the said Dan John was putte to correccion, and he wold no correccion take ne non obey, but presumptuosly in the chapiter kest of his abyt and wente oute from us alle dyspisyng and sayng ther shuld neyther priour, bisshop nor chancellor correct hym. And yet with help of William Wright, Richard Claybroke and other worshipfull men beyng present in the churche, Roger Acworth, John Belamy and other servaunts of the place, he was takyn and brought agayn. And ther the seid Dan John, affore us and thiese seid persones, declared and saith that Dan Thomas Dernton was as evell in the same synne as hee and wers, for he knewe and wyst hym in synne with a woman not long affore, wich woman was doghter to William Boweman of the paresh there. The said Dan Thomas denyed not ne said not nay at that tyme. Also at the same tyme, affore the seid Dan Thomas Dernton and affore the seid persones, the same Dan John saith that the same woman, that he was punysshyd fore, told hym that Dan Thomas Dernton labored her gretly to have his flesly justez with her and proferd her a girdyll and a nobyll, but she loved the forseid John so well she wold not agree therto; the same Dan John sayng thanne and mony tymez after that he wold abyde by that hit was thus as is afforeseid. Also the seid Dan John Garland, withoute auctorite ayenst his truth, haith receyved of William Baron a fermour to oure place iiij. mares in money unknowen to Dan Henry Leeke our officer and resceyvour, and the seid .iij. marcs presumptuosly withholdes. Moreover, the seid Dan Robert Marshall and Dan John Garland uppon Saint James Day last passed come unto the house of the kechen of the seid Priore, and ther vigorosly drought oute .ij. baslardes and with grete malice strake at a servant of our place called John Smyth and wolden have slayn him, but that .ij. of oure cokes letted theym, as God wold. And more over, the seid Dan John Garland and Dan Robert Marshall, not dredyng God nor kepyng theire devyne servis nor theire Religion, daily and nyghtly, at the said Priore and within the seid Cite of Yorke, rangeyng and jettyng uppe and doune with swerdes, baslardes and with other defensable array, nott willyng to abide no mans correccion but utterle despisis youre suppliant and all the bredren of the seid monestere. Wherefore your seid besecher prayeth youre goode lordship, consyderyng that he is nother of myght nor of power to punysh the said misdoers, and haath noon ordinare within the roialme of England to compleynt to, that the said mysdoers myght be punysshet be avise of youre lordeship as hit semeth best after your grete wysdom. And your suppliant shall dayly pray to God for the preservacion of your goode lordeship. 
This house was refounded by Ralf Paynell in 1089 for Benedictine monks as a cell to the abbey of St. Martin Marmoustier at Tours, which abbey had the exclusive patronage of the priors.

It was not suppressed with the other alien priories, but made denizen by a grant from Henry VI. dated 18th March, 1426 (Pat. 4 Henry VI. part ii. m. 8), conferring the right of election on the priory itself.

The petition of the priory on which this patent was granted is printed in Rolls of Parliament, iv. 302. The prior mentioned in this document, Robert Huby, is not included in Dugdale's list of priors. ${ }^{\mathrm{a}}$

The surname is not on the bill but on the answer, which follows.

\section{Bundle 47, No. 255.}

This is the answher of Dan Robert Marchall and Dan John Garlond, unto the bill of Dan Robert Huby, untrewly callyng hym Priour of the Holy Trinite of Yorke.

The said Robert Marchall and John Garlond sayn that thei have here as thei understand noon competent juge to her, decide and determine the materez conteigned in the said bill concernyng spirituell and relegious correccion. And if it be proved and thought by this court that thei have sufficient auctorite and poer, and be competent juges to here, decide and determine such materez conteigned in the said bill touchyng spirituell coreccion; than thei sayn that the said Robert Huby, namyng hymselfe Priour of the Holy Trinite of Yorke, is not ner aught not to be Priour ther, but on Thomas Darnton is and aught to be verray trewe Priour of the said place, and also is ordina[ry] and viker generall of ther said relegion, to whom of right and non other longeth and perteyneth all spirituell correccion. Moreover thei sayn that the mater conteigned in the said bill is untrewe and also [in] sufficient and noncerteyn to put them to answher. And over that the more part of the mater conteigned in the said bill is espirituell mater, and not determinable in this court, but in spirituell court, and with inne ther Relegion. And the residue of the mater is clerely determinable at the temporall lawe. And in which ${ }^{b}$ materez as be determinable by the comen lawe, thei ought not to be putt to answer withoute ther soverayn. For all which causez thei pray to be dismissed oute of this Court. And for more declaracion of the trougth, thei sayn and eyther of them saith, that for such offensez as touche espirituell correccion, if any such ther wer, thei have submitted them to the correccion of ther Relegion; and ther by the auctorite of ther souerayn and Religion they ben corrected and dispensed with; for which defautez and offencez if any such ther wer, thei understond not that thei

a Monasticon, iv. 680.

b Error for "such." 
ought eftesonez to be enpeched of. And as to the residue of the mater conteigned in the said bill, not gylty. All which the said Robert Marchall and John Garlond arn redy to prove as this Court will awarde, and prayen to be dismissed oute of this Court with ther resonable costez and damagez for ther untrewe vexacion, accordyng to the Statute in this cas purveyed.

These few specimens will, I think, be sufficient to show that the documents from which they have been selested, which have been hitherto but little known and not much used except by pedigree hunters, are worthy of being studied for several purposes, and will afford useful material to students of the English language, to students of the domestic manners and customs of our ancestors, and to students of the history of trade and commerce. 